\title{
Identification of Dialeurodes citri as a Vector of Citrus yellow vein clearing virus in China
}

Y. H. Zhang, C. H. Liu, Q. Wang, Y. L. Wang, C. Y. Zhou, ${ }^{\dagger}$ and Y. Zhou, ${ }^{\dagger}$ Citrus Research Institute, Southwest University, Chongqing, 400712, P. R. China, and Academy of Agricultural Sciences, Southwest University, Chongqing 400715, China

\begin{abstract}
In 2009, a new citrus viral disease caused by Citrus yellow vein clearing virus (CYVCV) was first discovered in China and now CYVCV is widely distributed in the field. CYVCV is transmissible by grafting and is spread by aphids from lemon to bean, and from bean to bean. However, until now, no vector has been shown to transmit CYVCV from citrus to citrus. In this study, after a 24-h acquisition access period (AAP), CYVCV was tested for in Dialeurodes citri (Ashmead), Panonychus citri McGregor, and Aphis citricidus (Kirkaldy) by quantitative RT-PCR.

After an AAP of $48 \mathrm{~h}$, groups of adults of D. citri, P. citri, and A. citricidus were given a $48 \mathrm{~h}$ inoculation access period on cultivar Daidai sour orange seedlings. Three, 6 , and 12 months post-transmission by $D$. citri, CYVCV was detected in the receptor plants, and the mean incidence of infected trees was $31.9,39.1$, and $39.1 \%$, respectively. CYVCV was not transmitted to citrus by $P$. citri or A. citricidus. This is the first report of the ability of $D$. citri to transmit CYVCV from infected to healthy citrus under laboratory conditions.
\end{abstract}

Yellow vein clearing disease of citrus, an emerging viral disease, was first reported from Pakistan in 1988 in lemon (Citrus limon Burm.f.) and sour orange (C. aurantium L.) (Catara et al. 1993). Subsequently, this disease was reported in commercial lemon trees in Turkey, India, and Iran (Alshami et al. 2003; Hashmian and Aghajanzadeh 2017; Önelge 2002). Yellow vein clearing disease was first observed on lemon cultivar Eureka in Ruili, Yunnan Province, China, in 2009 (Chen et al. 2014). Now, this disease is widely distributed in the major Chinese citrus-growing provinces and is considered to be the most serious disease affecting lemon production (Zhou et al. 2017).

Yellow vein clearing disease is caused by Citrus yellow vein clearing virus (CYVCV), which is a positive-sense RNA virus with a genome of $7.5 \mathrm{~kb}$ with six predicted open reading frames (ORFs) and is a putative member of the genus Mandarivirus, family Alphaflexiviridae (Loconsole et al. 2012). CYVCV is often symptomless in most citrus species, cultivars, and hybrids, but severe yellow vein clearing, leaf distortion, and veinal necrosis are symptoms expressed in lemon and sour orange (Chen et al. 2014; Loconsole et al. 2012; Zhou et al. 2017). Yellow vein clearing disease usually does not cause tree death, but can cause chronic yield reductions on lemon. In many lemon orchards in Anyue, Sichuan Province, where more than $80 \%$ of Chinese lemon production is concentrated, yellow vein clearing disease induces a marked 50 to $80 \%$ reduction in fruit yield, and a reduction in quality. Experimentation has shown that via mechanical transmission with sap extracts, CYVCV can infect Chenopodium quinoa Willd and $C$. amaranticolor, on which it induces local lesions, but it also systemically infects Phaseolus vulgaris var. Dermason and Vigna unguiculata (L.) with the development of chlorosis, severe mosaic, and necrosis (Önelge et al. 2011).

In citrus, CYVCV is transmitted through vegetative propagation of infected scion buds, or infected rootstocks, but also by mechanical

${ }^{\dagger}$ Corresponding authors: C. Y. Zhou, E-mail: zhoucy@cric.cn; Y.Zhou, E-mail: zhouyan@cric.cn

Funding: This work was supported in part by the Intergovernmental International Science, Technology and Innovation (STI) Collaboration Key Project of China's National Key R\&D Programme (NKP) (2017YFE0110900), Overseas Expertise Introduction Project for Discipline Innovation (111 Center) (B18044), Chongqing Research Program of Basic Research, and Frontier Technology (cstc2015jcyjBX0043), and Fundamental Research Funds for the Central Universities (XDJK2018AA002).

Accepted for publication 6 August 2018.

@ 2019 The American Phytopathological Society inoculations of sap extracts (Alshami et al. 2003). CYVCV can also be transmitted by Aphis craccivora Koch and A. spiraecola Patch from lemon to bean (P. vulgaris var. Dermason), and from bean to bean (Önelge et al. 2011). However, transmission tests from lemon to lemon with both species of aphid were unsuccessful (Önelge et al. 2011). To date, no tested vector species has been shown to transmit CYVCV from citrus to citrus. Field surveys showed that the citrus whitefly Dialeurodes citri (Ashmead), the citrus red mite Panonychus citri McGregor, and the brown citrus aphid Aphis citricidus (Kirkaldy) were prevalent in Chinese citrus orchards (Hu et al. 2010; Lagos et al. 2014; Wang et al. 2013; Zhou et al. 2011), and so were considered as likely vectors of CYVCV under natural conditions.

In this study, transmissions were conducted to determine the ability of D. citri, P. citri, and A. citricidus to acquire and transmit a local isolate of CYVCV from infected to healthy citrus under experimental conditions.

\section{Materials and Methods}

Maintenance of CYVCV. In 2014, CYVCV isolate CY-T1 was collected from a Eureka lemon tree in Chongqing Province of China. The tree displayed typical yellow vein clearing disease leaf symptoms such as yellow vein clearing, chlorosis, and leaf distortion. CY-T1 was graft-inoculated onto virus-free 5-year-old sweet orange cultivar Pineapple (C. sinensis [L.] Osbeck) seedlings as donor plants in the greenhouse at $20-25^{\circ} \mathrm{C}$. Virus infection was confirmed 20 days post inoculation by RT-PCR analysis as previously described (Chen et al. 2014). Eleven months post inoculation, the young spring flushes of CYVCV-infected donor plants expressed mild vein clearing, as described before (Chen et al. 2016).

Origins and maintenance of arthropods. Adults of D. citri, $P$. citri, and A. citricidus were collected from asymptomatic citrus plants that tested negative to CYVCV using RT-PCR (Chen et al. 2014) in a citrus orchard at the Citrus Research Institute, Chongqing, China, and identified to species according to morphology by using stereo microscopy. Adults of $D$. citri were fed on virus-free Pineapple sweet orange seedlings for 4 days and transferred to new virusfree seedlings every day to ensure a population of $D$. citri adults that was nonviruliferous. Adults of $P$. citri and A. citricidus also were fed on virus-free Pineapple sweet orange seedlings, and the eggs of $P$. citri and newly hatched individuals of $A$. citricidus were obtained and transferred to new virus-free Pineapple sweet orange seedlings in the greenhouse at $20-25^{\circ} \mathrm{C}$.

Total RNA was extracted with TRIzol reagent (Invitrogen, Carlsbad, CA) from 20 pools of 50 adults for each species obtained from the populations described above, and used for quantitative PCR (qPCR) assays for CYVCV as previously described (Chen et al. 
2016); CYVCV was not detected in any of these pooled samples. Based on the qPCR results, adults of each species were considered to be nonviruliferous and were maintained on virus-free Pineapple sweet orange seedlings in the greenhouse at $20-25^{\circ} \mathrm{C}$.

Standard curves. Primers CY4 and CY5 (which includes the T7 promoter sequence at its $5^{\prime}$ terminus) were used with to synthesize and amplify cDNA for in vitro transcription (Chen et al. 2016). RT-PCR products were transcribed in vitro with T7 RNA polymerase (Promega Corp., Madison, WI), and the transcripts were digested at $37^{\circ} \mathrm{C}$ for $30 \mathrm{~min}$ with RNase-free DNase I (Promega Corp., Madison, WI). The concentration of transcripts was estimated twice with a NanoDrop ND-2000 UV Spectrophotometer (Thermo Scientific, U.S.A.). For the generation of standard curves, 10 -fold serial dilutions $\left(10^{2}\right.$ to $\left.10^{9}\right)$ were prepared using RNA extracted (the starting concentration was $10 \mathrm{ng} / \mu \mathrm{l}$ ) from healthy citrus, and stored at $-80^{\circ} \mathrm{C}$.

Detection and quantification of CYVCV in arthropods. Adults of nonviruliferous D. citri, P. citri, and A. citricidus were placed on the young flushes of CYVCV-infected donor plants at $20-25^{\circ} \mathrm{C}$ for $24 \mathrm{~h}$. Pools of 50 adults of each species were placed in sterile microfuge tubes, respectively, and qPCR was used to assay the extracts for CYVCV (Chen et al. 2016). For each species, RNA extracted from 15 pools of 50 adults was tested for CYVCV. Four replicate volumes from each extract were analyzed by qPCR. The mean number of viral genomes was calculated plus standard error. The results were

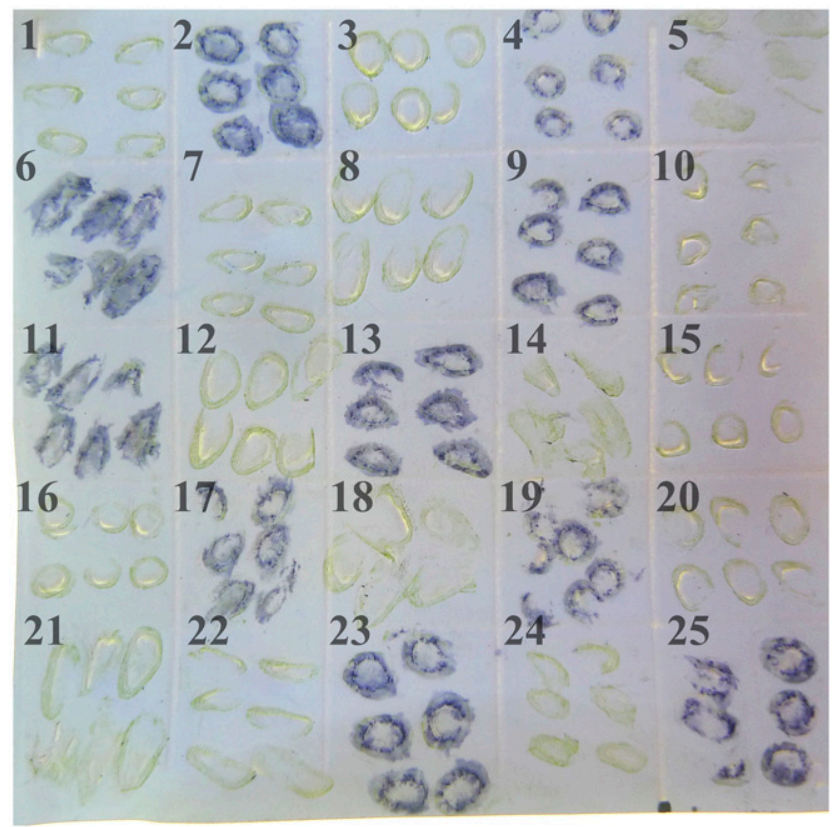

Fig. 1. Detection of Citrus yellow vein clearing virus (CYVCV) in cultivar Daidai sour orange seedlings by direct tissue blot immunoassay at 12 months post Dialeurodes citri (Ashmead) transmission. 2, 4, 6, 9, 11, 13, 17, 19, and 23: CYVCV-infected plants; $1,3,5,7,8,10,12,14,15,16,18,20,21$, and 22: noninfected plants; 24 : negative control; 25: positive control. subjected to ANOVA using SPSS software, and the $P$ values less than 0.001 were considered statistically significant (Gao et al. 2012).

For negative controls, RNA was extracted from five pools each of 50 adults of nonviruliferous $D$. citri, $P$. citri, and A. citricidus, that had been fed on virus-free Pineapple sweet orange seedlings for $24 \mathrm{~h}$ under the same conditions as described for virus-infected plants.

Cloning and sequencing. All qPCR amplicons were purified and cloned into pGEM-T easy vector (Promega Corp. Madison, WI). Three clones per qPCR amplicon were custom sequenced (Beijing Genomics Institute, Shengzhen, GD, China). Five sequences of CYVCV from each species were randomly selected and deposited in the GenBank database under accession numbers MH393602 M393606 (derived from D. citri), MH393607-MH393611 (derived from A. citricidus), and MH393612-M393616 (derived from P. citri). These sequences were identified by BLASTn analysis.

Acquisition of CYVCV. Adults of nonviruliferous D. citri, $P$. citri, and A. citricidus were placed on the young flushes of CYVCVinfected Pineapple sweet orange in insect-proof Perspex cages at $20-25^{\circ} \mathrm{C}$ for $48 \mathrm{~h}$.

Transmission of CYVCV by D. citri. After a 48-h acquisition access period (AAP), approximately 1,000 adults of $D$. citri were collected with a mouth aspirator and caged in Perspex for $48 \mathrm{~h}$ with 23 one-year-old virus-free cultivar Daidai sour orange seedlings, a variety that is symptomatic for CYVCV. As a negative control for transmission, approximately 1,000 nonviruliferous adults of $D$. citri were placed in a Perspex cage for 48 h with 23 one-year-old virus-free Daidai seedlings under the same conditions.

Transmission of CYVCV by $\boldsymbol{P}$. citri. After a 48-h AAP, adult mites were transferred to the young flushes of 1-year-old virus-free Daidai seedlings using a small watercolor paint brush, and given a 48-h inoculation access period (IAP). There were three treatments of 100,200 , and 300 mites per plant, and 23 receptor plants were used in each treatment. Furthermore, each treatment had a negative control group. The negative control group consisted of 15 virus-free plants, which were fed upon by nonviruliferous $P$. citri for $48 \mathrm{~h}$ under the same conditions.

Transmission of CYVCV by A. citricidus. After a 48-h AAP, apterous adult aphids were transferred to the young flushes of 1-yearold virus-free Daidai seedlings, and given a 48-h IAP. There were three treatments of 50,100, and 150 aphids per plant, with 29 receptor plants in each treatment. Furthermore, each treatment had a negative control group of 15 virus-free plants, which were fed upon by nonviruliferous $A$. citricidus for $48 \mathrm{~h}$ under the same conditions.

After inoculation, the receptor and control plants were treated with insecticide and maintained in an insect proof glasshouse at $20-25^{\circ} \mathrm{C}$ with a $16 \mathrm{~h} / 8 \mathrm{~h}$ light/dark photoperiod. Acquisitions and transmissions were repeated three times with each species to measure the variability in transmission rate.

Detection of CYVCV in the receptor plants. Three, 6, and 12 months after inoculation, the young flushes of the receptor and control plants were assayed for CYVCV by direct tissue blot immunoassay (DTBIA) using the monoclonal antibody (MAb) 18H5 (Bin et al. 2015; Z. Liu et al. 2016). Symptomatic tissues were sampled to test for CYVCV. If the plants didn't show symptoms to CYVCV, the asymptomatic tissues were sampled randomly from the young

Table 1. Detection of Citrus yellow vein clearing virus in cultivar Daidai sour orange seedlings after transmission by Dialeurodes citri (Ashmead)

\begin{tabular}{|c|c|c|c|c|c|c|}
\hline & \multicolumn{3}{|c|}{ CY-T1 } & \multicolumn{3}{|c|}{ Negative control } \\
\hline & $\begin{array}{l}\text { Three months } \\
\text { after inoculation }\end{array}$ & $\begin{array}{l}\text { Six months after } \\
\text { inoculation }\end{array}$ & $\begin{array}{l}\text { Twelve months after } \\
\text { inoculation }\end{array}$ & $\begin{array}{l}\text { Three months after } \\
\text { inoculation }\end{array}$ & $\begin{array}{l}\text { Six months after } \\
\text { inoculation }\end{array}$ & $\begin{array}{l}\text { Twelve months after } \\
\text { inoculation }\end{array}$ \\
\hline Trial 1 & $8 / 23^{y}$ & $8 / 23$ & $8 / 23$ & & & \\
\hline Trial 2 & $7 / 23$ & $10 / 23$ & $10 / 23$ & & & \\
\hline Trial 3 & $7 / 23$ & $9 / 23$ & $9 / 23$ & & & \\
\hline Total & $22 / 69$ & $27 / 69$ & $27 / 69$ & $0 / 69$ & $0 / 69$ & $0 / 69$ \\
\hline $\begin{array}{l}\text { Transmission rate } \\
(\text { mean } \pm S E)^{z}\end{array}$ & $0.319 \pm 0.033 \mathrm{a}$ & $0.391 \pm 0.033 \mathrm{a}$ & $0.391 \pm 0.033 \mathrm{a}$ & & & \\
\hline
\end{tabular}

\footnotetext{
${ }^{\mathrm{y}}$ Transmission expressed as the number of plants infected and denominator / number of test plants used.
}

${ }^{\mathrm{z}}$ Means followed by different letters are significantly different using one-way ANOVA method $(P=0.095)$. 
flushes. Six stem cross-sections were imprinted from each plant. A one-way ANOVA was applied to assess significant differences between the proportions of infected plants at the different sampling times.

\section{Results}

Detection and quantification of CYVCV in arthropods. In a previous study, CYVCV couldn't be quantified in single adults of D. citri, P. citri, or A. citricidus by qPCR (data not shown). In this study, the virus was detected by qPCR in pools of 50 adult $D$. citri, P. citri, and A. citricidus, with incidences of $100 \%$ (15 of 15), $100 \%$ (15 of 15$)$, and $53.3 \%(8 / 15)$, respectively, after a 24 -h AAP on CYVCV-infected plants. The mean numbers of viral genomes were $6.04 \times 10^{7} \pm 1.32 \times 10^{6}, 1.31 \times 10^{4} \pm 0.58 \times 10^{3}$, and $9.01 \times 10^{4} \pm$ $2.39 \times 10^{3}$ in D. citri, P. citri, and A. citricidus, respectively. Virus was not detected in the negative controls. Furthermore, according to the mean number of viral genomes quantified, significant differences were observed when CYVCV in $D$. citri was compared with the virus in $P$. citri $(P<0.001)$ and $A$. citricidus $(P<0.001)$. However, when $P$. citri and A. citricidus was compared, no significant difference was observed in the number of acquired viral genomes $(P=0.943)$.

Amplicons obtained from D. citri, P. citri, and A. citricidus were sequenced and shared $100.0 \%$ identity to a known CYVCV sequence (JX040635). These results indicated that D. citri, P. citri, and A. citricidus acquired CYVCV from infected citrus.

Transmission of CYVCV by $\boldsymbol{D}$. citri. Three months after inoculation, CYVCV was detected by DTBIA (Fig. 1) in the receptor plants with an incidence in the three trials of $34.8 \%$ (8/23), $30.4 \%$ (7/23), and 30.4\% (7/23), respectively, with a mean incidence of transmission of $31.9 \%$ (Table 1). Furthermore, the young flushes of CYVCV-positive receptor plants showed characteristic symptoms including yellow vein clearing, leaf distortion, and water soaking of veins on the ventral side. Six months post inoculation, the transmission incidence for CYVCV by D. citri was $34.8 \%$ (8/23), $39.1 \%$ (9/23), and $43.5 \%$ (10/23), respectively. The mean incidence of transmission was $39.1 \%$. Twelve months after inoculation, no additional CYVCV-infected receptor plants were detected (Table 1). The differences in the transmission incidence for CYVCV by D. citri at different sampling times were not statistically significant $(P=$ 0.095) (Table 1). No CYVCV was detected in the negative controls.

Transmission of CYVCV by $P$. citri and $A$. citricidus. Three, 6 , and 12 months after groups of $P$. citri and $A$. citricidus were allowed an IAP on Daidai seedlings, no CYVCV was detected in the receptor and negative control plants by DTBIA.

\section{Discussion}

CYVCV is an emerging citrus virus, having been identified first in Yunnan Province of China within the past nine years (Chen et al. 2014). The virus has spread rapidly and is now widespread in the major citrus-growing provinces in China (Zhou et al. 2017). The question that arises from the present study is, why is CYVCV spreading so quickly in China? Although it was shown that CYVCV could be transmitted by $A$. craccivora Koch and $A$. spiraecola Patch from lemon to bean and from bean to bean very effectively (Önelge et al. 2011), no previous work identified a vector that could transmit CYVCV from citrus to citrus (Loconsole et al. 2012).

Previous studies showed that populations of D. citri, P. citri, and A. citricidus are numerous in all citrus-growing areas of China ( $\mathrm{Hu}$ et al. 2010; Wang et al. 2013; Zhou et al. 2011). In this study, CYVCV was detected in adults of all three of these arthropod species, indicating that these arthropods might be the most likely to vector CYVCV. Previous studies with other vector-virus combinations showed that transmission incidence increased with larger vector populations, longer acquisition access feeding periods, and longer inoculation access feeding periods (Gray et al. 1991; Power et al. 1991). In this study, approximately 1,000 adults of $D$. citri and a 48-h AAP were used in the transmission experiments and the incidence of CYVCV in the receptor plants was detected by DTBIA up to 12 months after inoculation. Results from this study showed that
CYVCV was transmitted by $D$. citri and the incidence of transmission ranged from 31.9 to $39.1 \%$ depending on the sampling time. Therefore, $D$. citri is probably important for citrus to citrus spread of CYVCV in China. Although the sensitivity of DTBIA is less than qPCR, previous studies showed the consistency of detection of CYVCV by DTBIA compared with RT-PCR was $97.92 \%$ in different citrus varieties, and DTBIA is particularly useful for large-scale detection (Bin et al. 2015; Z. Liu et al. 2016). Furthermore, 12 months after inoculation, the incidence of CYVCV in the receptor plants tested by DTBIA and qPCR was consistent (data not shown). Additional studies are needed concerning the effect of $D$. citri growth stage and species of donor plant, the minimum acquisition and inoculation times, and the interaction of different $D$. citri sources and CYVCV isolates.

In a previous study, attempts to raise $D$. citri on Ligustrum lucidum Ait, a non-host plant for CYVCV, were unsuccessful (data not shown). Therefore, in this study, adults of $D$. citri collected from healthy plants in the citrus orchard were fed on virus-free Pineapple sweet orange seedlings for 4 days and transferred to new virus-free plants every day to ensure $D$. citri was nonviruliferous. In future studies, the use of non-host plants of CYVCV for feeding $D$. citri needs to be explored.

In this study, CYVCV was quantified in pools of 50 adults, with the results indicating that absence of transmission of the virus to citrus from a citrus source may be the result of a titer of CYVCV in $P$. citri and A. citricidus that is too low to initiate infection upon inoculation, as was observed with results from studies on vectors of Cauliflower mosaic virus (Escriu et al. 2000), Plum pox virus (Moreno et al. 2009), and Citrus tristeza virus (Zhou et al. 2011). Furthermore, mechanical transmission of CYVCV readily occurs using herbaceous hosts, suggesting that the virus may not be phloemlimited (Önelge et al. 2011). When P. citri was fed on the CYVCVinfected plants, the virions could be imbibed. This may explain why $P$. citri could acquire CYVCV under trial conditions.

Insects transmit many plant and animal viruses. S. Liu et al. (2016) suggested that gemycircularviruses such as Sclerotinia sclerotiorum hypovirulence-associated DNA virus 1 could be transmitted via insects which belong to different orders. In a recent study, under trial conditions similar to those in this study, CYVCV could be transmitted from sweet orange to sweet orange by A. spiraecola Patch (Zhang et al. 2018). Thus, CYVCV is also most likely to have a broad insect vector range, as $D$. citri and $A$. spiraecola Patch are distantly related phylogenetically and they belong to different families in the class Insecta. The acquisition and transmission of CTVCV by other insects common in citrus orchards, such as $A$. craccivora, $A$. (T.) aurantii Boyer de Fonscolombe, A. gossypii Glover, and other whitefly species needs to be explored.

In conclusion, this study presents the first evidence that CYVCV is transmitted by $D$. citri from infected to healthy citrus under laboratory conditions. Currently, the practiced control measures for CYVCV in China include using virus-free propagation material and the rogueing of symptomatic plants. This research fills an important gap in current knowledge of CYVCV transmission, which is critical for understanding the epidemiology of yellow vein clearing disease, developing control measures to reduce CYVCV spread, and screening for disease resistance.

\section{Literature Cited}

Alshami, A. A. A., Ahlawat, Y. S., and Pant, R. P. 2003. A hitherto unreported yellow vein clearing disease of citrus in India and its viral aetiology. Indian Phytopathol. 56:422-427.

Bin, Y., Song, Z., Li, Z. A., and Zhou, C. Y. 2015. Direct tissue blot immunoassay for detection of Citrus yellow vein clearing virus. Acta Hortic. Sin. 42: 1843-1850.

Catara, A., Azzaro, A., Davino, M., and Polizzi, G. 1993. Yellow vein clearing of lemon in Pakistan. Pages 364-367 in: International Organization of Citrus Virologists Conference Proceedings, vol. 12. P. Moreno, J. V. da Graca, and L. W. Timmer, eds. Riverside, CA. https://escholarship.org/uc/item/2v63f19n

Chen, H. M., Li, Z. A., Wang, X. F., Zhou, Y., Tang, K. Z., Zhou, C. Y., Zhao, X. Y., and Yue, J. Q. 2014. First report of Citrus yellow vein clearing virus on lemon in Yunnan, China. Plant Dis. 98:1747. 
Chen, H. M., Zhou, Y., Wang, X. F., Zhou, C. Y., Yang, X. Y., and Li, Z. A. 2016. Detection of Citrus yellow vein clearing virus based on a real-time RT-PCR approach. Acta Hortic. Sin. 43:168-174.

Escriu, F., Perry, K. L., and García-Arenal, F. 2000. Transmissibility of Cucumber mosaic virus by Aphis gossypii correlates with viral accumulation and affected by the presence of its satellite RNA. Phytopathology 90:1068-1072.

Gao, K., Deng, X. Y., Qian, H. Y., Wu, P., Qin, G. X., and Guo, X. J. 2012. Cloning, characterization, and expression analysis of a novel BmGDAPl gene from silkworm, Bombyx mori, involved in cytoplasmic polyhedrosis virus infection. Gene 497:208-213.

Gray, S. M., Power, A. G., Smith, D. M., Seaman, A. J., and Altman, N. S. 1991. Aphid transmission of Barley yellow dwarf virus: acquisition access periods and virus concentration requirements. Phytopathology 81:539-545.

Hashmian, B. S. M., and Aghajanzadeh, S. 2017. Occurrence of Citrus yellow vein clearing virus in citrus species in Iran. J. Plant Pathol. 99:290.

Hu, J. F., Wang, C. F., Wang, J., You, Y., and Chen, F. 2010. Monitoring of resistance to spirodiclofen and five other acaricides in Panonychus citri collected from Chinese citrus orchards. Pest Manag. Sci. 66:1025-1030.

Lagos, D. M., Voegtlin, D. J., Coeur d'acier, A., and Giordano, R. 2014. Aphis (Hemiptera: Aphididae) species groups found in the Midwestern United States and their contribution to the phylogenetic knowledge of the genus. Insect Sci. 21:374-391.

Liu, S., Xie, J. T., Cheng, J. S., Li, B., Chen, T., Fu, Y. P., Li, G. Q., Wang, M. Q., Jin, H. N., Wan, H., and Jiang, D. H. 2016. Fungal DNA virus infects a mycophagous insect and utilizes it as a transmission vector. Proc. Natl. Acad. Sci. USA 113:12803-12808.

Liu, Z., Sunzhu, Y. J., Zhou, X. P., Hong, J., and Wu, J. X. 2016. Monoclonal antibody-based serological detection of Citrus yellow vein clearing virus in citrus groves. J. Integr. Agric. 15:60345-60347.
Loconsole, G., Önelge, N., Potere, O., Giampetruzzi, A., Bozan, O., Satar, S., De Stradis, A., Savino, V., Yokomi, R. K., and Saponari, M. 2012. Identification and characterization of Citrus yellow vein clearing virus, a putative new member of the genus Mandarivirus. Phytopathology 102:1168-1175.

Moreno, A., Fereres, A., and Cambra, M. 2009. Quantitative estimation of Plum pox virus targets acquired and transmitted by a single Myzus persicae. Arch. Virol. 154:1391-1399.

Önelge, N. 2002. First report of yellow vein clearing of lemons in Turkey. J. Turk Phytopathol. 32:53-55.

Önelge, N., Satar, S., Elibüyük, Ö., Bozan, O., and Kamberoğlu, M. 2011. Transmission studies on Citrus yellow vein clearing virus. Pages 11-14 in: International Organization of Citrus Virologists Conference Proceedings, vol. 18. J. V. da Graca, R. F. Lee, and R. K. Yokomi, eds. Riverside, CA. https:// escholarship.org/uc/item/4134f1xr

Power, A. G., Seaman, A. J., and Gray, S. M. 1991. Aphid transmission of Barley yellow dwarf virus: inoculation access periods and epidemiological implications. Phytopathology 81:545-548.

Wang, P. P., Song, X. H., and Zhang, H. Y. 2013. Isolation and characterization of Aschersonia placenta from citrus orchards and its pathogenicity towards Dialeurodes citri (Ashmead). J. Invertebr. Pathol. 112:122-128.

Zhang, Y. H., Wang, Y. L., Wang, Q., Cao, M. J., Zhou, C. Y., and Zhou, Y. 2018 Identification of Aphis spiraecola as a vector of Citrus yellow vein clearing virus. Eur. J. Plant Pathol. 152:841-844.

Zhou, Y., Chen, H. M., Cao, M. J., Wang, X. F., Jin, X., Liu, K. H., and Zhou, C. Y. 2017. Occurrence, distribution and molecular characterization of Citrus yellow vein clearing virus in China. Plant Dis. 101:137-143.

Zhou, Y., Zhou, C. Y., Wang, X. F., Liu, Y. Q., Liu, K. H., Zou, Q., Xiang, Y., and Li, Z. A. 2011. Influence of the quantity and variability of Citrus tristeza virus on transmissibility by single Toxoptera citricidus. J. Plant Pathol. 93:97-103. 